\title{
Antecedents and Consequences of Job Embeddedness in the Egyptian Hospitality Context
}

Sameh Abd-elMaksoud Aboul-Dahab, Faculty of Commerce, Kafrelshiekh University, Egypt

\begin{abstract}
Although there are a growing body of studies on the influence of job embeddedness on turnover intention, few researches have been conducted on the drivers and outcomes of job embeddedness. Thus, this paper seeks to examine the drivers and outcomes of job embeddedness in the Egyptian hotel context. Data were collected from employees in the Egyptian hotels. Structural equation modelling was used to analyse the data. The results indicated that organisational support, employee advocacy, organisational rewards, and procedural justice are key drivers of job embeddedness. Furthermore, job embeddedness is related to organisational commitment and turnover intention. This study provides implications for the hospitality industry.
\end{abstract}

\section{KEYWORDS}

Employee Advocacy, Job Embeddedness, Organisational Commitment, Organisational Rewards, Organisational Support, Procedural Justice, Turnover Intention

\section{INTRODUCTION}

Worker turnover and the undeniable degrees of work portability in the friendliness labour forces are significant issues. The outcomes of representative turnover incorporate immediate and circuitous costs, for example, enlisting and preparing new workers and the deficiency of authoritative information when representatives leave (Fasbender, Van der Heijden, and Grimshaw, 2019; Sender, Rutishauser, and Staffelbach, 2018). Possible answers for high turnover incorporate expanding mentalities, for example, work fulfilment and hierarchical responsibility (Yang et al., 2020; Zhang et al., 2019). Nonetheless, while expanded degrees of occupation fulfilment and authoritative responsibility foresee lower aims to leave, they are frequently helpless indicators of real turnover (Akgunduz and Sanli, 2017; De Clercq, Haq, and Azeem, 2020).

Plainly different components are grinding away as far as work turnover, as has been noted (Coetzer et al., 2019), and further exploration is required in the neighbourliness and different businesses to comprehend the nature and part of this more extensive scope of variables. For instance, towards building up a more vigorous clarification of the variables affecting expectations to leave, a few agents have started to analyse the part of off-the-work factors, for example, the effect of harmony between serious and fun times (for example Ferreira, Martinez, Lamelas, and Rodrigues, 2017; Marasi, Cox, 
and Bennett, 2016). In any case, in a more extreme re-situating of the exploration, others contend that holes in our present arrangement are related with too incredible a concentration upon the reasons why individuals give up positions occupations instead of why individuals stay. Specifically, Mitchell and his associates (2001) at first speculated the work embeddedness build to represent the part of at work (for example individual arrangement with the work and association) and off-the-work (for example associations with the local area through history, family and social gatherings) factors that may impact worker perspectives and practices according to turnover. Itis proposed that these factors supersede work perspectives that would commonly incite goals to leave (Allen, Peltokorpi, and Rubenstein, 2016; Porter, Woo, and Campion, 2016).

As per "Social Exchange Theory" (SCT) (Blau, 1964) and "Norm of Reciprocity Theory" (NRT) (Gouldner, 1960), workers who see that their commitment is esteemed by the association create good inclination towards their work and association. Along these lines, deciding and applying administrative practices that mean to build workers' good insights about hierarchical help can assist representatives with creating good emotions towards their association. Cropanzano, Anthony, Daniels, and Hall (2017) contends that "individuals should help the individuals who help them" and "individuals ought not mischief the individuals who help them" during the time spent human exchange.

The ebb and flow study explores the nature and job of occupation embeddedness, specifically adding to the assortment of investigation into the design and effects of the build. While customary turnover hypothesis is prefaced on the idea that individuals will leave if their work fulfilment and authoritative responsibility are low, a task embeddedness 'maintenance' point of view fights that individuals will remain, given a specific blend of at work and off-the-work factors that make leaving disadvantageous. Fundamentally, this catches this present examination's maintenance approach, which accepts a positive attitude towards representative hierarchical responsibility. Initially, the current investigation applied occupation embeddedness to the setting of forefront inn labourers to test and approve the factor design of the build. Furthermore, the connection between the components of occupation embeddedness and other occupation related mentalities that are set up indicators of worker turnover was examined. This assessment of occupation embeddedness, related to hierarchical responsibility and goals to leave, looks at the utility of advancing position embeddedness as an elective methodology in the maintenance methodologies used to more readily oversee high staff turnover among forefront lodging labourers.

\section{RESEARCH BACKGROUND AND HYPOTHESES DEVELOPMENT}

\subsection{Job Embeddedness}

Set up hypothesis on deliberate turnover generally comes from crafted by Spring and Simon (1958) who set that apparent simplicity (for example the presence of occupation choices) and attractive quality (for example level of occupation fulfilment) of relinquishing one position join to foresee goals to leave. This model supports most of the ensuing disposition driven turnover research, with work fulfilment and hierarchical responsibility being two of the most generally operationalized factors (for example Ampofo, Coetzer, and Poisat, 2017; Chan, Ho, Sambasivan, and Ng, 2019). Nonetheless, while there are critical outcomes, the impacts are additionally powerless and many contend that insufficient consideration has been given to elective clarifications (see Akgunduz and Sanli, 2017).

Splitting away from this tight concentration upon mentality driven turnover research, the work embeddedness build proposes the part of three between related components (Lyu, and Zhu, 2019). To start with, network factors impact an individual's connection to their work. For instance, analysts, for example, Marshall, Chadwick and Marshall (1992) propose a 'overflow' model of turnover where work and everyday life associate. Moreover, Lee and Maurer (1999) found that hierarchical responsibility was not as solid an indicator of aim to leave as having a mate and additionally youngsters at home. Second, other authoritative elements that are not attitudinally based are exactly connected to turnover, 
incorporating working with specific individuals or ventures - these connections to groups, gatherings and errands have been marked as 'constituent responsibilities' (Thakur and Bhatnagar, 2017). Third, the 'unfurling model' of turnover (Darrat, Amyx, and Bennett, 2017) challenges customary models of turnover and portrays an assortment of thought processes in find employment elsewhere, a considerable lot of which are identified with outside 'stun' factors (Shehawy, Elbaz, and Agag, 2018). Morrell et al. (2004) propose that stuns, for instance horrendous conjugal breakdowns, impact goal to stop as well as firmly corresponded to "final irritation that will be tolerated" turnover choices. On the side of the 'unfurling model', negative perspectives and dynamic occupation search are not solid indicators of actual turnover (Yam, Raybould, and Gordon, 2018.). Together these three written works have situated occupation embeddedness as an elective way to deal with understanding the elements that shape will turnover aims and practices (Charlier, Guay, and Zimmerman, 2016).

Occupation embeddedness is "a wide arrangement of effects on a worker's choice to remain at work" (Holtom et al., 2006a, p. 319). The impacts are either at work (hierarchical embeddedness) or off-the-work (local area embeddedness) and these two measurements are autonomous from the conventional proportions of emotional responsibility, work fulfilment and saw work choices as approved by past exploration (see Arasli et al., 2017). These two measurements or impacts, are additionally separated into three factors; every one of which is addressed once in the authoritative embeddedness measurement and by and by locally embeddedness measurement. These six variables address the components a worker assesses when settling on the choice to remain in a task: fit, connections, and penance. Fit is characterized as: "a representative's apparent similarity or solace with an association and with their current circumstance" (Holtom et al., 2006a,p. 319). Connections are characterized as: "formal or casual associations between a representative and establishments or individuals" (Holtom et al., 2006a, p. 319). Penance is characterized as: "the apparent expense of material or mental advantages that are relinquished by authoritative takeoff" (Holtom et al., 2006a, pp. 319-320).

Albeit the first system (Shibiti, 2019) obviously elucidated six aspects of occupation embeddedness dwelling in two sub dimensions, there are presently contending positions about the construction of occupation embeddedness (Collins, and Mossholder, 2017). Over the long run, the develop has generally been operationalized as a composite of the two sub-measurements of authoritative and local area embeddedness (Zhang et al., 2019). In this total measure, every one of the 'fit', 'penance' and 'connection' aspects is similarly weighted and arrived at the midpoint of to shape the authoritative/ local area sub-components, and afterward again to frame generally speaking embeddedness (for example a "mean of means"; Mitchell et al., 2001, p.1111). As a rule, scientists operationalize the composite proportion of by and large work embeddedness (for example Qian, Yuan, Niu, and Liu, 2019). Nonetheless, there are different reasonable issues identified with the sub-measurements and individual aspects of occupation embeddedness. In the first place, blended outcomes on the side of an immediate connection between local area embeddedness and turnover could be clarified by a scope of variables. Zhang et al. (2019), for example, contend that the absence of prescient legitimacy gets from the individual aspect scales that contain the local area embeddedness sub-measurement, as variables are incorporated that don't generally liken to workers feeling "stuck" in their positions. Second, the 'joins' aspect isn't yet completely considered - the hidden standards of occupation embeddedness propose that the more associations a worker has, the more outlandish they are to leave (Susomrith, and Amankwaa, 2019). More isn't in every case fundamentally better, in any case, with more connections there is a higher possibility of clashing requests (Susomrith, and Amankwaa, 2019), and the quality and underlying attributes of connections should likewise be thought of (Zhang et al., 2019). Going to the cordiality business, its positions length the globe with many 'little world' organizations (Susomrith, and Amankwaa, 2019), and undoubtedly these associations may really pull representatives away instead of urge them to remain. Third, there are inquiries concerning the discriminant legitimacy of the 'fit' and 'penance' aspects of occupation embeddedness (Zhang et al., 2019). A worker who makes an evaluation that they 'fit' with their association would very probably see a 'penance' if they 
somehow managed to leave. Because of these issues, it is contended that joining aspect scale scores into one composite score keeps the special part from getting every individual feature.

\subsection{Turnover Intention}

The worker turnover rate is higher in the travel industry and lodging area than in different areas (Silaban, and Syah, 2018; Zhang, Ma, Xu, B. and Xu, 2019), and this is considered as the most tricky administration issue (Ohunakin, Adeniji, and Oludayo, 2018). On the off chance that the representatives who have elite levels and who are qualified find employment elsewhere, at that point this is very expensive and problematic for the association. Losing representatives who have elite will impede the collaboration of the association and will cause additional expenses as work force recharging and preparing. The turnover expectation is the main part of turnover conduct (Biswakarma, 2016). Therefore, the elements that impact turnover ought to be resolved and wiped out at the beginning phases. These variables might be controllable factors, for example, low occupation fulfilment, low authoritative commitment, high occupation stress, inner workforce market, and hierarchical equity, or they might be wild factors, for example, negative abstract structures, work jumping, and outside workforce market (Wen, Zhou, Hu, and Zhang, 2020).

End of business can be either intentional or compulsory. Compulsory end of work generally occurs on the events of terminating, being repetitive or passing of representative while the intentional end of business is up to the person's own will. Studies typically investigate representatives' wilful turnover aim of (Chiat, and Panatik, 2019). There are a few investigations that look at the contrary parts of wilful finish of work; nonetheless, supplanting the representative who left a task either deliberately or automatically with a more qualified individual can build the presentation of an association. In this way, the presence of high/low qualified representative competitors in the work market is a significant factor deciding if having workers who leave their posts is agreeable to the association or not. However, high representative turnover rate has become a persistent issue in the travel industry area. The turnover aim rate in the travel industry area in the UK was $67,6 \%$ in 2015 though the turnover rate among lodging directors in Australia was 39\%. Also, albeit the representative turnover rate in Taiwan is $33 \%$, over half of the workers leave the work in their first year. Chen and $\mathrm{Wu},(2017)$ contend that representatives' deliberate continuation of work can increment contingent upon positive hierarchical help insights, pioneer part trade (LME), and social change.

\subsection{Drivers of Job Embeddedness}

\subsubsection{Organisational Support}

Perceived organisational support (POS) is the overall conviction that the association really focuses on the commitments and government assistance of its workers (Zheng et al., 2018). Workers have a reasonable feeling of whether an association influences them in a good or a negative way. Workers are impacted by the organization's enthusiasm for their commitments to the associations and when the organization really focuses on their government assistance (Arasanmi, and Krishna, 2019; Kura, Shamsudin, and Chauhan, 2016). The apparent authoritative help should fulfill particularly certain necessities of the workers, for example, regard, reception, passionate help, and being affirmed (Alleyne, Hudaib, and Haniffa, 2018). The representatives' assumptions for being really focused on and being esteemed by their associations builds the trust of the workers that these associations will favor, remunerate and appreciate their perspectives and practices. The compensating of the association might be in the casual type of recognition or directing; or it could be in the more proper type of advancement or pay-rise (Pinna, De Simone, Cicotto, and Malik, 2020). An impression of expanded help from the association will cover the representative's requirements for endorsement, regard and social personality, it will deliver elite assumptions, and it will cause the worker to feel that additional job practices, accomplishment for the association, being valued by the association, and being compensated are totally upheld (Haar, de Fluiter, and Brougham, 2016). Figure 1 shows the study model. 


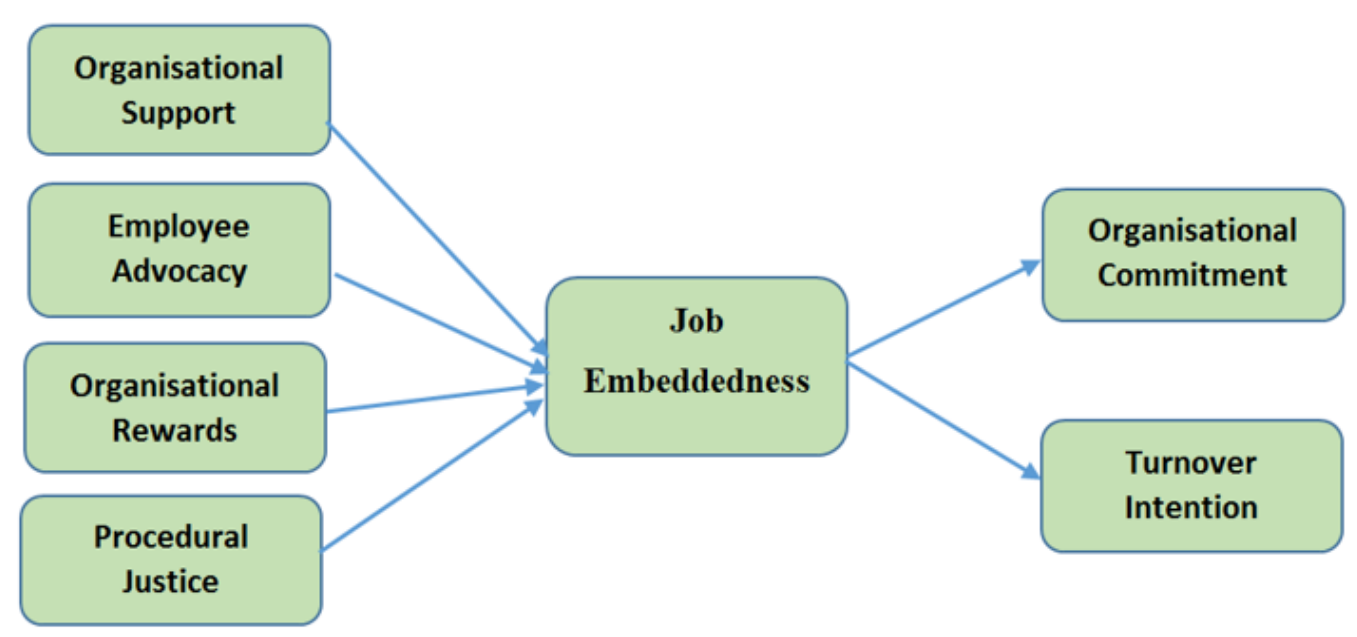

H1: Perceived organisational support has a significant influence on job embeddedness.

\subsubsection{Employee Advocacy}

Employee advocacy (EA) communicates the condition of being a volunteer on acting for the sake of the interests of the representatives, and shows the straightforwardness of the worker strategy of the association (Akgunduz, and Sanli, 2017). Worker backing incorporates issues, for example, thinking about the representatives' protests, shielding representatives from oppressive business works on, acting to workers in a legitimate way (advancement and move), shielding workers from provocation; it is likewise identified with the correspondence and portrayal of the concerns and objections of workers (Tsarenko, Leo, and Herman, 2018). The inside works on in regards to correspondence and representatives are reflected emphatically in the practices and the collaboration from multiple points of view of the representatives, and this expands the worker promotion discernment (Lee, 2021). The relations between the association and the representatives depend on a mutually beneficial idea, and they increment the uplifting disposition of the workers concerning their positions and associations (Men, and Yue, 2019). The acts of the associations that incorporate worker promotion are getting far and wide in associations where the representatives are seen as important while their appropriation is getting troublesome in associations where the representatives are considered as "useless" (Sonne, Guerreiro, and Wohlschlegel, 2018). The work fulfilment of the representatives who accept that their advantages are acknowledged as significant as the interests of the organization increments and their turnover aim diminishes (Grimpe, Kaiser, and Sofka, 2019).

H2: Employee advocacy has a significant influence on job embeddedness.

\subsubsection{Organisational Rewards}

Both unmistakable (for example pay and incidental advantages) and immaterial (for example acknowledgment) rewards given by the association ought to emphatically impact worker JE, particularly the penance measurement. Clearly, the more rewards a worker gets from the association, the more prominent the potential penance the person in question would make by stopping. Obviously, if the worker can get a new line of work with better prizes at another association, at that point the 
individual in question isn't probably going to feel those misfortunes. However, until the representative really joins this new boss, the individual in question is making the supposition that the prizes will really be better than those offered by the current manager. All in all, the penance of good rewards is an undeniable chance. On the other hand, in the event that the worker doesn't have a superior other option, the person unquestionably makes a penance. This contention is steady with the outcomes from past examination (Appelbaum et al., 2000) in which authoritative prizes have been appeared to improve representatives' connection to the association, and hence implant them all the more profoundly into their positions. Consequently, the accompanying speculation is proposed:

H3: Organisational rewards have a significant influence on job embeddedness.

\subsubsection{Procedural Justice}

Hierarchical equity is the general impression of what is reasonable in the work environment (Greenberg, 1990). Of the three significant sorts of equity - distributive, procedural and interactional - procedural has been appeared to strongest affect representative results like POS, work fulfillment, hierarchical responsibility and aim to stop (Rhoades and Eisenberger, 2002). Subsequently, this is the solitary structure considered in this examination. Additionally, on the grounds that procedural equity is the apparent reasonableness of the techniques used to allot results (Thibaut and Walker, 1975; Leventhal, 1980; Lind and Tyler, 1988; Greenberg, 1993), there are reasons why it ought to be identified with JE. Reasonable, open methodology utilized in disseminating results is probably going to be seen by workers as an advantage given by the association, particularly when those representatives have had contribution to creating them. Workers who decide to leave a "reasonable" association obviously risk forfeiting their present fair climate for another association with less equity (Yao et al., 2004). Likewise, representatives who are dealt with reasonably by their manager are probably going to encounter a more noteworthy feeling of fit with the association, expecting, obviously, they esteem reasonable treatment. Alternately, on account of out of line treatment from the association, most workers presumably won't have this feeling of fit and subsequently would not forfeit much should they leave (Yao et al., 2004). Subsequently, it is normal that JE will be affected by procedural equity:

H4: Procedural justice has a significant influence on job embeddedness.

\subsection{Outcomes of Job Embeddedness}

\subsubsection{Organisational Commitment}

There is calculated and experimental help for a general hypothesis of occupation turnover with various investigations revealing that work embeddedness is a huge indicator of goals to leave (for example Berkovich and Bogler, 2020; Chang et al., 2016). In numerous examinations, work fulfilment and authoritative responsibility are less critical indicators of expectations than work embeddedness (Khan, Ali, A., Khan, and Jehan, 2019). A few agents (for example Filimonau, Derqui, and Matute, 2020) fight that work embeddedness supplements as opposed to replaces the conventional attitudinal based models of turnover. On the side of this position, they secured position embeddedness clarifies a lot of change far in excess of proportions of occupation fulfilment and authoritative responsibility. Turnover choices are not just about occupation perspectives, work market openings and socioeconomics, yet additionally about the measure of genuine and saw attachment to one's work and one's local area (Haque, Fernando, and Caputi, 2019).

H5: Job embeddedness has a significant influence on organisational commitment. 


\subsubsection{Turnover Intention}

The worker turnover rate is higher in the travel industry and lodging area than in different areas (Cohen, Blake, and Goodman, 2016), and this is considered as the most dangerous administration issue (Kim, Tam, Kim, and Rhee, 2017). In the event that the workers who have elite levels and who are qualified find employment elsewhere, at that point this is incredibly expensive and problematic for the association. Losing representatives who have superior will thwart the cooperation of the association and will cause additional expenses as faculty restoration and preparing. The turnover goal is the main part of turnover conduct (Kumar, Jauhari, Rastogi, and Sivakumar, 2018). Thus, the components that impact turnover ought to be resolved and killed at the beginning phases. These components might be controllable factors, for example, low occupation fulfilment, low authoritative commitment, high occupation stress, inward workforce market, and hierarchical equity, or they might be wild factors like negative abstract structures, work bouncing, and outer workforce market (Park, and Min, 2020).

End of business can be either wilful or compulsory. Compulsory end of work typically occurs on the events of terminating, being repetitive or demise of representative though the intentional end of business is up to the person's own will. Studies generally investigate representatives' wilful turnover aim of (Fazio, Gong, Sims, and Yurova, 2017). There are a few examinations that analyse the contrary parts of wilful finish of business; notwithstanding, supplanting the representative who left a task either intentionally or automatically with a more qualified individual can expand the presentation of an association. Thusly, the presence of high/low qualified representative up-and-comers in the work market is a significant factor deciding if having workers who leave their posts is agreeable to the association or not. However, high representative turnover rate has become a persistent issue in the travel industry area. The turnover goal rate in the travel industry area in the UK was $67,6 \%$ in 2015 while the turnover rate among lodging chiefs in Australia was 39\%. Essentially, albeit the worker turnover rate in Taiwan is 33\%, over half of the representatives leave the work in their first year. Sun and Wang, (2017) contend that representatives' deliberate continuation of work can increment contingent upon positive authoritative help discernments, pioneer part trade (LME), and social change.

H6: Job embeddedness has a significant influence on turnover intention.

\section{METHODOLOGY}

\subsection{Sample}

This examination utilized a quantitative approach and an organized survey to gather information from individuals working in hotels in Egypt. A connection containing the online poll was shipped off 500 employees in the hotels industry in Egypt who were mentioned to give the review to their workers, bringing about 380 usable surveys. The survey didn't contain obligatory inquiries regarding personality and the members were guaranteed that their obscurity and privacy would be kept up. Among the members, 195 (51.32 percent) were male and 185 (48.73 percent) were female. The normal age of the members was 28.87 years, the work experience of the members was 4,8 years and their normal tenure in the hotel was 3.1 years.

\subsection{Measure}

"Job embeddedness": to test Job embeddedness, a seven-item scale produced by Crossley et al. (2007) was administered. A sample from the scale was: "It would be difficult for me to leave my organisation". The aggregate measure was chosen because this measure was used in past literature investigating the relationship between HR activities and turnover intent (Hom et al., 2009). We assessed Employee advocacy utilising four items adopted from Yeh (2014). Organisational support was measured using a scale from Eisenberger et al. (1986). Both organisational rewards and procedural justice measurements 
have been adopted from Nguyen et al (2016). Organisational commitment was measured using 4 items developed by Meyer and Parfyonova, (2010) and Crossley et al. (2007). Turnover intention was evaluated utilising four items adapted from Crossley et al. (2007).

\section{DATA ANALYSIS AND RESULTS}

\subsection{Measurement Model}

A confirmatory factor analysis (CFA) was conducted to evaluate the reliability and validity of the study measurements. The findings of the model offered adequate evidence of a model fit $\left(\chi^{2}=1600.55, \chi^{2} / \mathrm{DF}=1.76, \mathrm{p}<0.001, \mathrm{CFI}=0.96\right.$, GFI $=0.87, \mathrm{NFI}=0.93$, and RMSEA $=0.04)$. Standardized loading estimates of all items are above 0.50. The Cronbach's alpha coefficients varied from 0.73 to 0.95 , promoting internal consistency within each construct between measurement objects. The study further evaluated the composite reliability of each build to validate the overall fit of the final measurement model. As shown in Table 1, the results showed reasonable reliability of composites, ranging from 0.98 to 0.84 . All average variance values were above 0.50, which demonstrated evidence of convergent validity (Hair et al., 2019). Table 2 indicated that the squared AVE is higher than the squared correlation coefficients among each construct (Fornell and Larcker, 1981).

\subsection{Structural Model Assessment}

Figure 2 shows the main results of our study. Goodness-of-fit statistics demonstrated a good fit of the conceptual framework to the data: $\left(\chi^{2}=1750.23, \chi^{2} / \mathrm{DF}=1.49, \mathrm{p}<0.001\right.$, CFI $=0.97$, $\mathrm{GFI}=0.88, \mathrm{NFI}=0.94$, and $\mathrm{RMSEA}=0.05)$. The study variables explains $71 \%$ of the variance in organisational commitment and $63 \%$ of the variance in turnover intention. The results indicated that both organisational support and employee advocacy have a significant influence on job embeddedness $(\beta=0.39,0.58, \mathrm{p}<0.00)$. Organisational rewards and procedural justice are related to job embeddedness $(\beta=0.41,0.19, \mathrm{p}<0.00)$. Furthermore, the link between job embeddedness and organisational commitment and turnover intention was significant $(\beta=0.68,-0.43, \mathrm{p}<0.00)$. Thus, H1, H2, H3, H4, H5, \& H6 are supported.

\section{DISCUSSION AND CONCLUSION}

\subsection{Key Findings}

This paper seeks to examine the influences of perceived organizational support and employee advocacy on job embeddedness and the impact of it on turnover intention and organisational commitment. To start with, it was anticipated that organizational support would positively affect work embeddedness. This speculation is upheld. The discoveries show that representatives who see that their association upholds them have more elevated levels of occupation embeddedness and have inspirational perspectives towards their work. Second, it was normal that worker support would positively affect work embeddedness. This speculation is likewise upheld. This discovering underpins the contention that representatives who see that businesses esteem their inclinations have inspirational perspectives towards their association.

The third theory anticipated that apparent authoritative help would have a huge negative impact on turnover goal. The discoveries show that when the lodging workers comprehend that they are being upheld then the turnover goal diminishes. The outcomes detailed in this examination with respect to the apparent hierarchical help give off an impression of being a possible answer for decline willful turnover goals of workers. 
Table 1. Measurement statistics of construct scales

\begin{tabular}{|c|c|c|c|c|c|}
\hline Construct/Indicators & $\begin{array}{l}\text { Indicator } \\
\text { loadings }\end{array}$ & CR & VIF & Cronbach's $\alpha$ & AVE \\
\hline $\begin{array}{l}\text { Job embeddedness } \\
\text { EMB1 } \\
\text { EMB2 } \\
\text { EMB3 } \\
\text { EMB4 } \\
\text { EMB5 } \\
\text { EMB6 } \\
\text { EMB7 }\end{array}$ & $\begin{array}{l}0.94 \\
0.95 \\
0.95 \\
0.92 \\
0.90 \\
0.93 \\
0.89\end{array}$ & 0.97 & 1.382 & 0.95 & 0.59 \\
\hline $\begin{array}{l}\text { Organisationnel support } \\
\text { ORG1 } \\
\text { ORG2 } \\
\text { ORG3 } \\
\text { ORG4 }\end{array}$ & $\begin{array}{l}0.93 \\
0.96 \\
0.94 \\
0.93\end{array}$ & 0.95 & 2.932 & 0.93 & 0.63 \\
\hline $\begin{array}{l}\text { Employee advocacy } \\
\text { ADV1 } \\
\text { ADV2 } \\
\text { ADV3 } \\
\text { ADV4 }\end{array}$ & $\begin{array}{l}0.95 \\
0.98 \\
0.92 \\
0.95\end{array}$ & 0.95 & 1.738 & 0.93 & 0.61 \\
\hline $\begin{array}{l}\text { Organisational rewards } \\
\text { ORW1 } \\
\text { ORW2 } \\
\text { ORW3 }\end{array}$ & $\begin{array}{l}0.94 \\
0.90 \\
0.92\end{array}$ & 0.93 & 1.928 & 0.90 & 0.63 \\
\hline $\begin{array}{l}\text { Procedural justice } \\
\text { PRJ1 } \\
\text { PRJ2 } \\
\text { PRJ3 } \\
\text { PRJ4 }\end{array}$ & $\begin{array}{l}0.93 \\
0.95 \\
0.89 \\
0.91\end{array}$ & 0.95 & 2.031 & 0.93 & 0.51 \\
\hline $\begin{array}{l}\text { Organisational commitment } \\
\text { COM1 } \\
\text { COM2 } \\
\text { COM3 } \\
\text { COM4 }\end{array}$ & $\begin{array}{l}0.94 \\
0.97 \\
0.90 \\
0.94\end{array}$ & 0.96 & 2.129 & 0.94 & 0.54 \\
\hline $\begin{array}{l}\text { Turnover intention } \\
\text { TUR1 } \\
\text { TUR2 } \\
\text { TUR3 } \\
\text { TUR4 }\end{array}$ & $\begin{array}{l}0.98 \\
0.93 \\
0.93 \\
0.94\end{array}$ & 0.96 & 2.203 & 0.95 & 0.62 \\
\hline
\end{tabular}

\subsection{Managerial Implications}

In view of the consequences of this investigation, there are two significant ramifications for business practice that could be helpful structure an administrative viewpoint. To start with, the chiefs of the lodgings should ensure that there is a hierarchical environment where workers may communicate their feelings in an agreeable way; and may feel that their commitments are valued by the association and their own advantages are really focused on. Second, lodging workers have connections with clients and adapt to various client solicitations and grievances. Consequently, worker applicants whose abilities and perspectives are reliable with the tentative arrangements, purposes, and estimations of the association ought to be remembered for the stock cycle of the association and put in the offices where representatives work vis-à-vis with the clients. Since the work embeddedness of the representatives who feel nearer with the hierarchical purposes and qualities will be higher, their deliberate turnover 
Table 2. Discriminant Validity of the Correlations between Constructs

\begin{tabular}{|l|l|l|l|l|l|l|l|}
\hline \multirow{2}{*}{ Construct } & \multicolumn{7}{|c|}{ Correlations and square roots of AVE } \\
\cline { 2 - 8 } & \multicolumn{1}{|c|}{ EMB } & \multicolumn{1}{|c|}{ ORG } & ADV & \multicolumn{1}{|c|}{ COM } & \multicolumn{1}{c|}{ TUR } & ORW & PRJ \\
\hline EMB & $\mathbf{0 . 7 9 2 a}$ & & & & & & \\
\hline ORG & $0.3940 \mathrm{~b}$ & $\mathbf{0 . 8 4 0}$ & & & & & \\
\hline ADV & 0.509 & 0.654 & $\mathbf{0 . 7 9 4}$ & & & & \\
\hline COM & 0.453 & 0.503 & 0.465 & $\mathbf{0 . 8 4 9}$ & & & \\
\hline TUR & 0.620 & 0.612 & 0.604 & 0.643 & $\mathbf{0 . 7 9 0}$ & & \\
\hline ORW & 0.473 & 0.392 & 0.610 & 0.349 & 0.450 & $\mathbf{0 . 8 0 4}$ & \\
\hline PRJ & 0.530 & 0.452 & 0.349 & 0.540 & 0.340 & 0.406 & $\mathbf{0 . 7 3 6}$ \\
\hline
\end{tabular}

Note: (a) Composite reliabilities are along the diagonal, (b) Correlations

Figure 2.

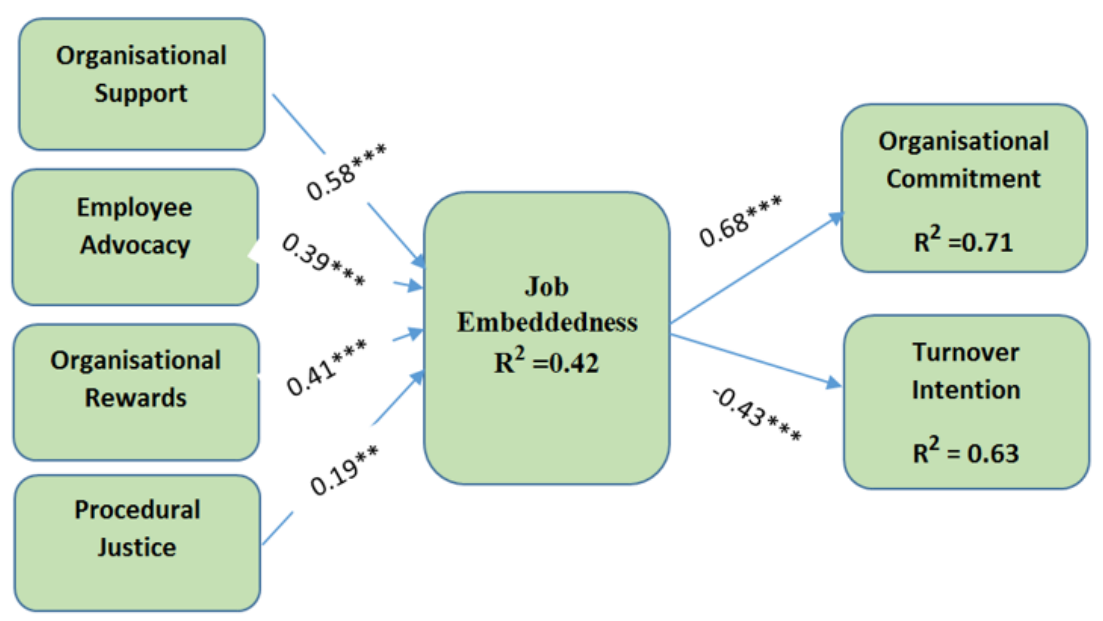

goal will be lower. Likewise, inn chiefs can expand the work embeddedness of their representatives by setting out open doors through which workers can develop themselves, by making workers utilize their abilities in a proficient way, by aiding their vocation arranging, and by applying cooperation in the association. To improve view of hierarchical help, chiefs need to impart plainly to representatives that the association thinks often about them and qualities their commitments. Remunerating workers well, giving freedoms to advancements and improvement and treating them genuinely in the methods used to disseminate results, for model, would help pass on this message. By doing this, directors would expand the probability that workers feel a commitment to remain on their positions and contribute back to the association. Third, inn directors ought to give happy with working conditions to their representatives, act in a legitimate way, guarantee that representatives are remembered for the authoritative choice cycles that are straightforwardly identified with laborers, lastly consider the objections and recommendations of the workers, along these lines causing them to feel that they are upheld by their associations. In this manner inn chiefs will build the work embeddedness of their representatives; and thusly, the deliberate turnover goal will diminish. 


\subsection{Theoretical Contribution}

Social Exchange Theory and Norm of Reciprocity Theory proposed by Gouldner (1960) and Blau (1964) contend that individuals give back as opposed to give hurt when some help is offered to them. This contention is tried in this exploration. Results show that apparent hierarchical help expands the work embeddedness of the representatives and diminishes the turnover aims. This exploration bolsters crafted by Akgunduz and Sanli (2017) and Jiang et al (2012) who recommend that workers who see that they are esteemed and their privileges are secured show better perspectives towards their associations to give back. Workers' work embeddedness brings about various advantages, like expansion in occupation fulfilment, consumer loyalty, and diminishing in turnover expectation (Crossley, Bennett, Jex, and Burnfield, 2007; Robinson et al., 2014). The outcomes announced in this investigation show that apparent authoritative help seems, by all accounts, to be the expected arrangement. This is steady with other observational examinations which report that hierarchical help discernment expands work embeddedness just as with RNT. This outcome shows that the work embeddedness of the representatives who see that their necessities are upheld and their commitments are considered as significant by the association increments at a huge level. In this exploration it was discovered that when representatives see that there are worker promotion rehearses then their work embeddedness increments. This discovering calls attention to that when representatives see that their advantages are secured, that data is shared uninhibitedly, and that administration attempts to expand their fulfilment then their work embeddedness increments. What's more, a negative connection is secured between position embeddedness and turnover expectation in this exploration. This discovering upholds crafted by Crossley et al. (2007) and Karatepe (2013) who contend that representatives' end of work may carry monetary and non-material expenses to them and harm their fit associations with the association and society. This examination additionally showed that representative support doesn't influence the deliberate turnover aim of workers. As per this discovering, representatives' longing to keep on working in the association isn't influenced by the decision of inn the board to utilize business support.

\section{LIMITATIONS AND FUTURE RESEARCH}

There are a few impediments in this investigation which additionally prepare for future exploration. In the first place, this study focused on hotels in Egypt and this may debilitate the generalizability of the examination discoveries. Another limit is the testing technique. The basic inspecting strategy, which is one of the non-irregular examining techniques, has been utilized in this investigation. The craving of the creators to remember each worker for the inspecting has been powerful in this inclination. An extra impediment of this examination is that it inspected the authoritative help and representative support just from the point of view of workers. Future exploration could expect to distinguish the practices of lodging directors towards their representatives so the worker discernments and administrator practices are coordinated. The information assortment period could likewise be stretched out throughout a more drawn out timeframe as hierarchical help and worker promotion are not every day exercises. 


\section{REFERENCES}

Akgunduz, Y., \& Sanli, S. C. (2017). The effect of employee advocacy and perceived organizational support on job embeddedness and turnover intention in hotels. Journal of Hospitality and Tourism Management, 31, 118-125. doi:10.1016/j.jhtm.2016.12.002

Allen, D. G., Peltokorpi, V., \& Rubenstein, A. L. (2016). When "embedded" means "stuck": Moderating effects of job embeddedness in adverse work environments. The Journal of Applied Psychology, 101(12), 1670-1686. doi:10.1037/ap10000134 PMID:27559625

Alleyne, P., Hudaib, M., \& Haniffa, R. (2018). The moderating role of perceived organisational support in breaking the silence of public accountants. Journal of Business Ethics, 147(3), 509-527. doi:10.1007/s10551-015-2946-0

Ampofo, E. T., Coetzer, A., \& Poisat, P. (2017). Relationships between job embeddedness and employees' life satisfaction. Employee Relations, 39(7), 951-966. doi:10.1108/ER-10-2016-0199

Arasanmi, C. N., \& Krishna, A. (2019). Employer branding: Perceived organisational support and employee retention-the mediating role of organisational commitment. Industrial and Commercial Training, 51(3), 174-183. doi:10.1108/ICT-10-2018-0086

Arasli, H., Bahman Teimouri, R., Kiliç, H., \& Aghaei, I. (2017). Effects of service orientation on job embeddedness in hotel industry. Service Industries Journal, 37(9-10), 607-627. doi:10.1080/02642069.2017.1349756

Berkovich, I., \& Bogler, R. (2020). Conceptualising the mediating paths linking effective school leadership to teachers' organisational commitment. Educational Management Administration \& Leadership. doi: $10.1177 / 1741143220907321$

Biswakarma, G. (2016). Organizational career growth and employees' turnover intentions: An empirical evidence from Nepalese private commercial banks. International Academic Journal of Organizational Behavior and Human Resource Management, 3(2), 10-26.

Blau, P. M. (1964). Justice in social exchange. Sociological Inquiry, 34(2), 193-206. doi:10.1111/j.1475682X.1964.tb00583.x

Chan, W. L., Ho, J. A., Sambasivan, M., \& Ng, S. I. (2019). Antecedents and outcome of job embeddedness: Evidence from four and five-star hotels. International Journal of Hospitality Management, 83, 37-45. doi:10.1016/j.ijhm.2019.04.011

Chang, K., Nguyen, B., Cheng, K. T., Kuo, C. C., \& Lee, I. (2016). HR practice, organisational commitment \& citizenship behaviour. Employee Relations, 38(6), 907-926. doi:10.1108/ER-12-2015-0218

Charlier, S. D., Guay, R. P., \& Zimmerman, R. D. (2016). Plugged in or disconnected? A model of the effects of technological factors on employee job embeddedness. Human Resource Management, 55(1), 109-126. doi:10.1002/hrm.21716

Chen, T. J., \& Wu, C. M. (2017). Improving the turnover intention of tourist hotel employees. International Journal of Contemporary Hospitality Management, 29(7), 1914-1936. doi:10.1108/IJCHM-09-2015-0490

Chiat, L. C., \& Panatik, S. A. (2019). Perceptions of employee turnover intention by Herzberg's motivationhygiene theory: A systematic literature review. Journal of Research in Psychology, 1(2), 10-15. doi:10.31580/ jrp.v1i2.949

Coetzer, A., Inma, C., Poisat, P., Redmond, J., \& Standing, C. (2019). Does job embeddedness predict turnover intentions in SMEs? International Journal of Productivity and Performance Management, 68(2), 340-361. doi:10.1108/IJPPM-03-2018-0108

Cohen, G., Blake, R. S., \& Goodman, D. (2016). Does turnover intention matter? Evaluating the usefulness of turnover intention rate as a predictor of actual turnover rate. Review of Public Personnel Administration, 36(3), 240-263. doi:10.1177/0734371X15581850

Collins, B. J., \& Mossholder, K. W. (2017). Fairness means more to some than others: Interactional fairness, job embeddedness, and discretionary work behaviors. Journal of Management, 43(2), 293-318. doi:10.1177/0149206314527132 
Cropanzano, R., Anthony, E. L., Daniels, S. R., \& Hall, A. V. (2017). Social exchange theory: A critical review with theoretical remedies. The Academy of Management Annals, 11(1), 479-516. doi:10.5465/annals.2015.0099

Crossley, C. D., Bennett, R. J., Jex, S. M., \& Burnfield, J. L. (2007). Development of a global measure of job embeddedness and integration into a traditional model of voluntary turnover. The Journal of Applied Psychology, 92(4), 1031-1042. doi:10.1037/0021-9010.92.4.1031 PMID:17638463

Crossley, C. D., Bennett, R. J., Jex, S. M., \& Burnfield, J. L. (2007). Development of a global measure of job embeddedness and integration into a traditional model of voluntary turnover. The Journal of Applied Psychology, 92(4), 1031-1042. doi:10.1037/0021-9010.92.4.1031 PMID:17638463

Darrat, M. A., Amyx, D. A., \& Bennett, R. J. (2017). Examining the impact of job embeddedness on salesperson deviance: The moderating role of job satisfaction. Industrial Marketing Management, 63, 158-166. doi:10.1016/j. indmarman.2016.10.012

De Clercq, D., Haq, I. U., \& Azeem, M. U. (2020). Perceived contract violation and job satisfaction: Buffering roles of emotion regulation skills and work-related self-efficacy. The International Journal of Organizational Analysis, 28(2), 383-398. doi:10.1108/JOA-07-2019-1837

Eisenberger, R., Armeli, S., Rexwinkel, B., Lynch, P. D., \& Rhoades, L. (2001). Reciprocation of perceived organizational support. The Journal of Applied Psychology, 86(1), 42-51. doi:10.1037/0021-9010.86.1.42 PMID:11302232

Fasbender, U., Van der Heijden, B. I., \& Grimshaw, S. (2019). Job satisfaction, job stress and nurses' turnover intentions: The moderating roles of on-the-job and off-the-job embeddedness. Journal of Advanced Nursing, 75(2), 327-337. doi:10.1111/jan.13842 PMID:30187541

Fazio, J., Gong, B., Sims, R., \& Yurova, Y. (2017). The role of affective commitment in the relationship between social support and turnover intention. Management Decision, 55(3), 512-525. doi:10.1108/MD-05-2016-0338

Ferreira, A. I., Martinez, L. F., Lamelas, J. P., \& Rodrigues, R. I. (2017). Mediation of job embeddedness and satisfaction in the relationship between task characteristics and turnover. International Journal of Contemporary Hospitality Management, 29(1), 248-267. doi:10.1108/IJCHM-03-2015-0126

Filimonau, V., Derqui, B., \& Matute, J. (2020). The COVID-19 pandemic and organisational commitment of senior hotel managers. International Journal of Hospitality Management, 91, 102659. doi:10.1016/j.ijhm.2020.102659 PMID:32904709

Fornell, C. \& Larcker, D.F. (1981). Structural equation models with unobservable variables and measurement error: Algebra and statistics. Academic Press.

Gouldner, A. W. (1960). The norm of reciprocity: A preliminary statement. American Sociological Review, 25(2), 161-178. doi:10.2307/2092623

Grimpe, C., Kaiser, U., \& Sofka, W. (2019). Signaling valuable human capital: Advocacy group work experience and its effect on employee pay in innovative firms. Strategic Management Journal, 40(4), 685-710. doi:10.1002/ smj. 2957

Haar, J. M., de Fluiter, A., \& Brougham, D. (2016). Abusive supervision and turnover intentions: The mediating role of perceived organisational support. Journal of Management \& Organization, 22(2), 139-153. doi:10.1017/ jmo.2015.34

Hair, J. F., Risher, J. J., Sarstedt, M., \& Ringle, C. M. (2019). When to use and how to report the results of PLSSEM. European Business Review, 31(1), 2-24. doi:10.1108/EBR-11-2018-0203

Haque, A., Fernando, M., \& Caputi, P. (2019). The relationship between responsible leadership and organisational commitment and the mediating effect of employee turnover intentions: An empirical study with Australian employees. Journal of Business Ethics, 156(3), 759-774. doi:10.1007/s10551-017-3575-6

Hom, P. W., Tsui, A. S., Wu, J. B., Lee, T. W., Zhang, A. Y., Fu, P. P., \& Li, L. (2009). Explaining employment relationships with social exchange and job embeddedness. The Journal of Applied Psychology, 94(2), 277-297. doi:10.1037/a0013453 PMID:19271791 
Jiang, K., Liu, D., McKay, P. F., Lee, T. W., \& Mitchell, T. R. (2012). When and how is job embeddedness predictive of turnover? A meta-analytic investigation. The Journal of Applied Psychology, 97(5), 1077-1096. doi:10.1037/a0028610 PMID:22663557

Karatepe, O. M. (2013). High-performance work practices, work social support and their effects on job embeddedness and turnover intentions. International Journal of Contemporary Hospitality Management, 25(6), 903-921. doi:10.1108/IJCHM-06-2012-0097

Khan, A. N., Ali, A., Khan, N. A., \& Jehan, N. (2019). A study of relationship between transformational leadership and task performance: The role of social media and affective organisational commitment. International Journal of Business Information Systems, 31(4), 499-516. doi:10.1504/IJBIS.2019.101583

Kim, S., Tam, L., Kim, J. N., \& Rhee, Y. (2017). Determinants of employee turnover intention. Corporate Communications, 22(3), 308-328. doi:10.1108/CCIJ-11-2016-0074

Kumar, M., Jauhari, H., Rastogi, A., \& Sivakumar, S. (2018). Managerial support for development and turnover intention. Journal of Organizational Change Management, 31(1), 135-153. doi:10.1108/JOCM-06-2017-0232

Kura, K.M., Shamsudin, F.M., \& Chauhan, A. (2016). Organisational trust as a mediator between perceived organisational support and constructive deviance. International Journal of Business and Society, 17(1).

Lee, Y. (2021). Bridging employee advocacy in anonymous social media and internal corporate social responsibility (CSR). Management Decision. Advance online publication. doi:10.1108/MD-01-2020-0101

Lyu, Y., \& Zhu, H. (2019). The predictive effects of workplace ostracism on employee attitudes: A job embeddedness perspective. Journal of Business Ethics, 158(4), 1083-1095. doi:10.1007/s10551-017-3741-x

Marasi, S., Cox, S. S., \& Bennett, R. J. (2016). Job embeddedness: Is it always a good thing? Journal of Managerial Psychology, 31(1), 141-153. doi:10.1108/JMP-05-2013-0150

Men, L. R., \& Yue, C. A. (2019). Creating a positive emotional culture: Effect of internal communication and impact on employee supportive behaviors. Public Relations Review, 45(3), 101764. doi:10.1016/j. pubrev.2019.03.001

Meyer, J. P., \& Parfyonova, N. M. (2010). Normative commitment in the workplace: A theoretical analysis and re-conceptualization. Human Resource Management Review, 20(4), 283-294. doi:10.1016/j.hrmr.2009.09.001

Ohunakin, F., Adeniji, A., \& Oludayo, O. (2018). Perception of frontline employees towards career growth opportunities: Implications on turnover intention. Business: Theory and Practice, 19(0), 278-287. doi:10.3846/ btp. 2018.28

Park, J., \& Min, H. K. (2020). Turnover intention in the hospitality industry: A meta-analysis. International Journal of Hospitality Management, 90, 102599. doi:10.1016/j.ijhm.2020.102599

Pinna, R., De Simone, S., Cicotto, G., \& Malik, A. (2020). Beyond organisational support: Exploring the supportive role of co-workers and supervisors in a multi-actor service ecosystem. Journal of Business Research, 121, 524-534. doi:10.1016/j.jbusres.2020.02.022

Porter, C. M., Woo, S. E., \& Campion, M. A. (2016). Internal and external networking differentially predict turnover through job embeddedness and job offers. Personnel Psychology, 69(3), 635-672. doi:10.1111/ peps. 12121

Qian, S., Yuan, Q., Niu, W., \& Liu, Z. (2019). Is job insecurity always bad? The moderating role of job embeddedness in the relationship between job insecurity and job performance. Journal of Management \& Organization, 1-17. doi:10.1017/jmo.2018.77

Robinson, R. N., Kralj, A., Solnet, D. J., Goh, E., \& Callan, V. (2014). Thinking job embeddedness not turnover: Towards a better understanding of frontline hotel worker retention. International Journal of Hospitality Management, 36, 101-109. doi:10.1016/j.ijhm.2013.08.008

Sender, A., Rutishauser, L., \& Staffelbach, B. (2018). Embeddedness across contexts: A two-country study on the additive and buffering effects of job embeddedness on employee turnover. Human Resource Management Journal, 28(2), 340-356. doi:10.1111/1748-8583.12183 
Shehawy, Y. M., Elbaz, A., \& Agag, G. M. (2018). Factors affecting employees' job embeddedness in the Egyptian airline industry. Tourism Review, 73(4), 548-571. doi:10.1108/TR-03-2018-0036

Shibiti, R. (2019). Satisfaction with retention factors in relation to job embeddedness of public school teachers. SA Journal of Human Resource Management, 17, 9. doi:10.4102/sajhrm.v17i0.1161

Silaban, N., \& Syah, T. Y. R. (2018). The influence of compensation and organizational commitment on employees' turnover intention. IOSR Journal of Business and Management, 20(3), 1-6.

Sonne, H., Guerreiro, J., \& Wohlschlegel, B. (2018, June). Increasing awareness and reputation of MERCK SA Portugal through employee advocacy. In Academy of Marketing Science World Marketing Congress (pp. 619-633). Springer.

Sun, R., \& Wang, W. (2017). Transformational leadership, employee turnover intention, and actual voluntary turnover in public organizations. Public Management Review, 19(8), 1124-1141. doi:10.1080/14719037.201 6.1257063

Susomrith, P., \& Amankwaa, A. (2019). Relationship between job embeddedness and innovative work behaviour. Management Decision, 58(5), 864-878. doi:10.1108/MD-11-2018-1232

Thakur, S. J., \& Bhatnagar, J. (2017). Mediator analysis of job embeddedness: Relationship between work-life balance practices and turnover intentions. Employee Relations, 39(5), 718-731. doi:10.1108/ER-11-2016-0223

Tsarenko, Y., Leo, C., \& Herman, H. M. (2018). When and why do social resources influence employee advocacy? The role of personal investment and perceived recognition. Journal of Business Research, 82, 260-268. doi:10.1016/j.jbusres.2017.09.001

Wen, B., Zhou, X., Hu, Y., \& Zhang, X. (2020). Role stress and turnover intention of front-line hotel employees: The roles of burnout and service climate. Frontiers in Psychology, 11, 36. doi:10.3389/fpsyg.2020.00036 PMID:32082216

Yam, L., Raybould, M., \& Gordon, R. (2018). Employment stability and retention in the hospitality industry: Exploring the role of job embeddedness. Journal of Human Resources in Hospitality \& Tourism, 17(4), 445-464. doi:10.1080/15332845.2018.1449560

Yang, C., Chen, Y., Roy, X. Z., \& Mattila, A. S. (2020). Unfolding deconstructive effects of negative shocks on psychological contract violation, organizational cynicism, and turnover intention. International Journal of Hospitality Management, 89, 102591. doi:10.1016/j.ijhm.2020.102591

Zhang, L., Fan, C., Deng, Y., Lam, C. F., Hu, E., \& Wang, L. (2019). Exploring the interpersonal determinants of job embeddedness and voluntary turnover: A conservation of resources perspective. Human Resource Management Journal, 29(3), 413-432. doi:10.1111/1748-8583.12235

Zhang, X., Ma, L., Xu, B., \& Xu, F. (2019). How social media usage affects employees' job satisfaction and turnover intention: An empirical study in China. Information \& Management, 56(6), 103136. doi:10.1016/j. im.2018.12.004

Zheng, Y., Wang, J., Doll, W., Deng, X., \& Williams, M. (2018). The impact of organisational support, technical support, and self-efficacy on faculty perceived benefits of using learning management system. Behaviour \& Information Technology, 37(4), 311-319. doi:10.1080/0144929X.2018.1436590

Sameh Abd-elMaksoud Mohamed Abd-elMaksoud Aboul-Dahab is a Business Administration Lecturer. Quality Unit Manager in Faculty of Commerce, Kafrelshiekh University, Egypt. Ph.D. \& MBA from Faculty of Commerce, Cairo University, Egypt. 